\title{
Sex Determination of Bovine Embryos Using H-Y Antibodies
}

\author{
By Birthe Avery and Mette Schmidt \\ Department of Reproduction, \\ Royal Veterinary and Agricultural University, Copenhagen, Denmark.
}

\begin{abstract}
Avery, B. and M. Schmidt: Sex determination of bovine embryos using H-Y antibodies. Acta vet. scand. 1989, 30, 155-164. -6 days old bovine embryos $(n=$ 126) were obtained from 8 superovulated cows or heifers by flushing the uteri and oviducts either non-surgially or after slaughter. Part of the embryos $(n=72)(\mathrm{mo}-$ rula stages) were placed in Ham's F-10 or PBS supplemented with $10 \%$ fetal calf serum (FCS) diluted 1:1 with supernatant from the $\mathrm{H}-\mathrm{Y}$ antibody producing clone and cultured at $38^{\circ} \mathrm{C}$, in $5 \% \mathrm{CO}_{2} / 95 \%$ arr and $100 \%$ humidity. Control embryos $(n=54)$ were cultured in $\mathrm{H}-\mathrm{Y}$ antibody free medium.

After culture the embryos could be separated into a blastocyst- and a morula group. A subsequent colchemid and hypotonic treatment and fixation and Giemsa staining allowed a precise karyotyping, and thus sex determination for $36 \mathrm{H}-\mathrm{Y}$ antibody treated embryos and 22 control embryos. The limiting factor for proper karyotyping was lack of metaphases, incomplete methaphases or poor preparation. Among the H-Y antibody treated embryos we found 7 males and 15 females in the blastocyst and 14 males and 0 females in the morula group. A statistical analysis of these proportions led to the conclusion that the $\mathrm{H}-\mathrm{Y}$ antibody had a significant influence on the sex ratio.
\end{abstract}

sex rat1o; cattle; karyotyping; monoclonal antibodies.

\section{Introduction}

The H-Y antigen was first described by Eichwald \& Silmser in 1955 as a male-specifik weak transplantation antigen system. It is found in the cell membrane of almost all nucleated male mammalian cells and appears to be highly conserved throughout evolution, as mouse $\mathrm{H}-\mathrm{Y}$ antibodies are known to cross react with $\mathrm{H}-\mathrm{Y}$ antigen from seventy different species (Wachtel et al. 1974, 1975, Wachtel 1983, Silvers \& Wachtel 1977, Nakamura et al. 1984).

It has been questioned whether the male specific antigen which can be detected serologically is the same as the originally described transplantation antigen (Melvold et al. 1977, Wachtel et al. 1984), but for all practical purposes they are considered to be identical and hence the terminology $\mathrm{H}-\mathrm{Y}$ antigen is used.

In addition to being detected on adult somatic nucleated cells and sperm (Bennett \& Boyse 1973, Goldberg et al. 1971, Hoppe \& Koo 1984, Koo et al. 1973, Zaborskl 1979) $\mathrm{H}-\mathrm{Y}$ antigen was also found on 8-cell mouse embryos by Krco \& Goldberg (1976). They observed that half of the mouse embryos died when incubated with H-Y antibody and complement. Later Epstein et al. (1980) were able to show by karyotyping that $92 \%$ of the surviving embryos were females. Besides being found on mouse embryos, H-Y antigen has been demonstrated on embryos from other mammalian species: rat, rabbit, 
pig, sheep, cow, goat and horse. This lack of species specificity combined with the presence of a $\mathrm{H}-\mathrm{Y}$ antigen on male embryos has made mouse $\mathrm{H}-\mathrm{Y}$ antibody of potential use in the embryo transfer industry as a mean to control sex ratio, although it is still at the experimental stage (reviewed by Anderson (1987) and Wachtel (1984)).

Until now sexing of embryos by means of $\mathrm{H}-\mathrm{Y}$ antibodies has been attempted by the following 3 methods:

a) Incubation with $\mathrm{H}-\mathrm{Y}$ antibody and complement, which leads to destruction of the male embryos (White et al. 1982, 1983, Wachtel 1984, Shelton \& Goldberg 1984).

b) Incubation with $\mathrm{H}-\mathrm{Y}$ antibody followed by FITC-labelled goat-anti-mouse-immunoglobulin. The FITC-labelling allow visualization of male embryos and full viability of both sexes (Wachtel 1984, White et al. 1983, 1984, 1987).

c) Incubation in $\mathrm{H}-\mathrm{Y}$ antibody containing medium for some hours, after which a normally developing blastocyst group (females) and a reversibly arrested morula group (males), both viable, can be separated (Utsumi et al. 1983, 1984).

The last method was based on the observation that after culturing rat morulas in $\mathrm{H}-\mathrm{Y}$ antibody containing medium, the development of half of the embryos was temporarily arrested. After being transferred to recipients, the male ratio from the blastocysts was
$20 \%$. The same effect was seen in cow and goat morulas (Utsumi et al. 1983, 1984). This non-invasive and non-destructive approach for sexing cattle embryos seemed very attractive, and the present experiment was undertaken to test the efficiency of our $\mathrm{H}-\mathrm{Y}$ antibody on bovine embryos using the Utsumi method.

\section{Materials and methods}

\section{Embryo source}

Eight to 14 days after estrus dairy cows and heifers were stimulated with either a single injection of 1500-3000 I U. PMSG ${ }^{\mathrm{a}}(\mathrm{n}=5)$ or injections of $32-40 \mathrm{mg} \mathrm{FSH}^{\mathrm{b}}(\mathrm{n}=4)$ given twice daily in decreasing doses for 5 days. 72 $\mathrm{h}$ after the initial injection the animals were given $0.75 \mathrm{mg}$ cloprostenol $^{\mathrm{c}}$ to cause luteal regression. Insemination occurred at 12 and 24 hours after onset of heat, and at day 6 the uteri were flushed non-surgically or surgically after slaughter. The flushing medium was Dulbecco's phosphate-buffered saline (PBS).

\section{Embryo evaluation}

Morphological evaluation was based on developmental stages and quality (Lindner \& Wright 1983):

\footnotetext{
a Antex ${ }^{(R)}$, Leo Pharmaceuticals, Ballerup, Denmark.

b FHS-P, Burns Biotec, Omaha, Nebraska, USA.

c Estrumat ${ }^{(R)}$, Vet, Lundbeck and Co. Valby, Denmark.
} 
Developmental stages

\begin{tabular}{|c|c|c|}
\hline Age & Stage & Description \\
\hline day 5 & morula (M) & $\begin{array}{l}32-64 \text { cells in a ball; the cellular mass occupies almost all of the } \\
\text { perivitelline space }\end{array}$ \\
\hline day 6 & $\begin{array}{l}\text { compact } \\
\text { morula }(\mathrm{CM})\end{array}$ & $\begin{array}{l}64 \text { cells which have "fused" into a compact mass of homogenous } \\
\text { structure. The cell mass occupies } 60-70 \% \text { of the perivitelline space. }\end{array}$ \\
\hline day 6-7 & $\begin{array}{l}\text { young bla- } \\
\text { stocyst (YB) }\end{array}$ & $\begin{array}{l}\text { The embryo begins to form blastocoele which is a fluid filled cavity. } \\
\text { The embryo occupies up to } 70-80 \% \text { of the perivitelline space, and } \\
\text { up to } 50 \% \text { is blastocoele. (Signet ring). }\end{array}$ \\
\hline day 7 & $\begin{array}{l}\text { blastocyst } \\
\text { (BL) }\end{array}$ & $\begin{array}{l}\text { The embryo occupies } 80-100 \% \text { of the perivitelline space, and the } \\
\text { blastocoelom occupies more than } 50 \% \text { of the embryo. }\end{array}$ \\
\hline day 8 & $\begin{array}{l}\text { expanded bla- } \\
\text { stocyst }(\mathrm{XB})\end{array}$ & $\begin{array}{l}\text { The diameter increases } 1.5 \text { times, and as a result the zona pellucida } \\
\text { becomes very thin. The inner cell mass is small and compact. }\end{array}$ \\
\hline day 9 & $\begin{array}{l}\text { hatched bla- } \\
\text { stocyst (HA) }\end{array}$ & $\begin{array}{l}\text { The hatching process takes } 8-12 \text { hours, where the zona pellucida } \\
\text { is being shed. }\end{array}$ \\
\hline
\end{tabular}

Quality. The quality was based on morphology divided into 4 grades: excellent (A), good (B), fair (C), poor (D).

\section{Embryoculture}

Embryos were cultured in Hams F-10 medium (Flow), supplemented with glutamin 4 $\mathrm{mM}$, penicillin $200 \mathrm{IE} / \mathrm{ml}$, streptomycinsulphate $100 \mu \mathrm{g} / \mathrm{ml}$ and $10 \%$ fetal calf serum (FCS) (Seralab), or in Dulbeccos PBS medium (from our own pharmacy) containing glucose $1000 \mathrm{mg} / \mathrm{l}$, pyruvate $36 \mathrm{mg} / \mathrm{l}$, kanamycinsulphate $25 \mathrm{mg} / \mathrm{l}$, BSA $4 \mathrm{~g} / \mathrm{l}$ supplemented with $10 \%$ FCS or $10 \%$ steer serum, in Nunc 4-well dishes at $38^{\circ} \mathrm{C}$ in $5 \%$ $\mathrm{Co}_{2} / 95 \%$ air and $100 \%$ humidity.

Supernatant from the H-Y antibody producing clone, cultured in RPMI-1640 (Flow) supplemented with $10 \%$ FCS provided the $\mathrm{H}-\mathrm{Y}$ antibody, which was diluted 1:1 with the embryo culture medium.

\section{Karyotyping and sex determination}

These procedures were similar to those described previously (Avery et al. 1989).
Production of monoclonal $H-Y$ antibody

Serum from multiparous female BALB/c mice (8-12 litters) was tested for the presence of H-Y antibody by a cytotoxicity assay against sperm (Krupen-Brown \& Wachtel 1979, Pledrahita \& Anderson 1985, Dooher \& Bennett 1977, Goldberg et al. 1971). Three days before fusion, $5 \times 10^{7}$ male spleen cells from the same strain was given intraperitoneally to one of the $\mathrm{H}-\mathrm{Y}$ antibody positive multiparous mice. The spleen cells from the female mouse were fused with cells from the BALB/c mouse myeloma cell line P3-X63-Ag8-U1 (PU) in the presence of PEG using standard techniques (Köhler \& Milstein 1975, Kenneth \& McKearn 1980, Gefter et al. 1977, Goding 1980, Yelton et al. 1978).

The hybridoma supernatants were tested for $\mathrm{H}-\mathrm{Y}$ antibody activity by an ELISA technique on living confluent monolayers of primary epidermal cells from newborn female and male Wistar rats. One clone was found to react with male but not with female cells. The hybridoma supernatants were also tes- 
ted on Daudi cell supernatant coated onto ELISA plates. (Daudi cells, ATCC no. CCL213). (Bradley \& Heslop 1984, Brunner et al. 1984, Meck et al. 1984, Nagamine et al. 1984). The same clone was found to react. Daudi cells are beta- 2 microglobulin deficient male B-lymphoblasts, which are secreting $\mathrm{H}-\mathrm{Y}$ antigen to the surrounding medium. Cells from the clone producing $\mathrm{H}-\mathrm{Y}$ antibodies was subcloned by limiting dilution, and supernatant from this clone, which is still producing IgM antibodies was used in the present study.

\section{Experiments and results}

Eight donors were flushed at day 6 , i.e. at the expected day for the embryos being at the morula stage, yielding 126 embryos.
Thirty five percent $(n=44)$ of the embryos were quality $A, 46 \%(n=58)$ and $19 \%(n=$ 24) were quality $B$ and $C$, respectively. Five different experiments were set up, and the embryos were divided into a $\mathrm{H}-\mathrm{Y}$ antibody group (A) $(n=72)$ and a control group (B) (n $=54)$. The control embryos were cultured under identical conditions in $\mathrm{H}-\mathrm{Y}$ antibodyfree medium. It was attempted to allocate the embryos in such a way that embryo number, -quality and -stages were comparable for group A and B. The distribution of the developmental stages and the allocation into the 5 experiments is seen in Table 1 .

During culture the embryos were evaluated every second hour. When approximately half of the $\mathrm{H}-\mathrm{Y}$ antibody treated embryos had developed into blastocysts, they were

Table 1. Embryo development of group A and B embryos

\begin{tabular}{|c|c|c|c|c|c|c|}
\hline \multirow[b]{2}{*}{ Exp } & \multirow[b]{2}{*}{ Group } & \multirow[b]{2}{*}{$\begin{array}{l}\text { Inttal embryo } \\
\text { development }\end{array}$} & \multicolumn{2}{|c|}{ Blastocysts } & \multicolumn{2}{|c|}{ Compact morulas } \\
\hline & & & development & $\begin{array}{l}\text { hours in } \\
\text { culture }\end{array}$ & development & $\begin{array}{l}\text { hours in } \\
\text { culture }\end{array}$ \\
\hline \multirow[t]{2}{*}{1} & A & $8 \mathrm{CM}$ & $2 \mathrm{BL}$ & 17 & $6 \mathrm{CM}$ & 17 \\
\hline & B & $1 \mathrm{BL}, 2 \mathrm{YB}$ & $1 \mathrm{XB}, 2 \mathrm{BL}$ & 17 & 0 & \\
\hline \multirow[t]{2}{*}{2} & Á & $9 \mathrm{CM}$ & $4 \mathrm{BL}$ & 15 & $5 \mathrm{CM}$ & 19 \\
\hline & B & $8 \mathrm{CM}$ & $5 \mathrm{BL}$ & 15 & $3 \mathrm{CM}$ & 19 \\
\hline \multirow[t]{2}{*}{3} & A & $20 \mathrm{CM}$ & $11 \mathrm{BL}$ & 11 & $9 \mathrm{CM}$ & 14 \\
\hline & B & $20 \mathrm{CM}$ & $13 \mathrm{BL}$ & 10 & $7 \mathrm{CM}$ & 10 \\
\hline \multirow[t]{2}{*}{4} & A & $19 \mathrm{CM}$ & $12 \mathrm{BL}$ & 10 & $7 \mathrm{CM}$ & 13 \\
\hline & B & $19 \mathrm{CM}$ & $15 \mathrm{BL}$ & 10 & $4 \mathrm{CM}$ & 10 \\
\hline \multirow[t]{2}{*}{5} & A & $16 \mathrm{CM}$ & $10 \mathrm{BL}$ & 4 & $6 \mathrm{CM}$ & 4 \\
\hline & B & 4 YB & $4 \mathrm{BL}$ & 4 & 0 & \\
\hline \multirow[t]{2}{*}{ Total } & A & 72 & $39 \mathrm{BL}$ & & $33 \mathrm{CM}$ & \\
\hline & B & 54 & $40 \mathrm{BL}$ & & $14 \mathrm{CM}$ & \\
\hline
\end{tabular}

A: embryos cultured in Hams F-10/10\% FCS (exp. 1 and 2), in PBS/10\% FCS (exp. 3 and 4) or in PBS/10\% steer serum (exp. 5) diluted 1:1 in super natant from the $\mathrm{H}-\mathrm{Y}$ antibody clone. Following culture two groups were distinguished: blastocysts and compact morulas.

B: control embryos cultured under identical conditions in H-Y antibody free medium. 
divided into 2 groups (BL and $\mathrm{CM}$ ) and transferred to fresh H-Y antibody free medium. The BL were colchemid treated and karyotyped immediately after, the CM were cultured for $0-4 \mathrm{~h}$ longer before colchemid treatment and karyotyping. The control embryos were cultured and karyotyped parallel to the $\mathrm{H}-\mathrm{Y}$ antibody treated embryos.

Table 1 also shows, that following culture for group A embryos in H-Y antibody containing medium, 39 embryos (54\%) developed to blastocysts, while 33 embryos (46\%) remained at the compact morula stage. In the control group (B), 40 embryos (74\%) developed into blastocysts, and 14 (26:\%) embryos stayed at the compact morula stage at the end of the experiment. This difference was statistically significant (chi square $=$ 5.229, $\mathrm{p}=0.022, \mathrm{DF}=1$ ).

The outcome of the karyotyping is shown in Table 2. In the H-Y antibody treated group of embryos (A), 7 males and 15 females versus 14 males and 0 females were found among the blastocysts and compact morulas, respectively. In group $\mathbf{A}$, embryo sex and embryo stage was significantly correlated, with blastocysts predominantly being females and compact morulas being males (chi

Table 2-1. Embryo development and karyotyping of the H-Y antibody treated embryos (Group A).

\begin{tabular}{|c|c|c|c|c|c|c|c|c|}
\hline \multirow[b]{3}{*}{ Exp } & \multicolumn{4}{|c|}{ Blastocysts } & \multicolumn{4}{|c|}{ Compact morulas } \\
\hline & \multicolumn{4}{|c|}{ typed } & \multicolumn{4}{|c|}{ typed } \\
\hline & no embryos & male & female & not typed & no embryos & male & female & not typed \\
\hline 1 & 2 & 0 & 1 & 1 & 6 & 3 & 0 & 3 \\
\hline 2 & 4 & 0 & 1 & 3 & 5 & 1 & 0 & 4 \\
\hline 3 & 11 & 2 & 4 & 5 & 9 & 4 & 0 & 5 \\
\hline 4 & 12 & 3 & 5 & 4 & 7 & 4 & 0 & 3 \\
\hline 5 & 10 & 2 & 4 & 4 & 6 & 2 & 0 & 4 \\
\hline Total & 39 & 7 & 15 & 17 & 33 & 14 & 0 & 19 \\
\hline
\end{tabular}

Table 2-2. Embryo development and karyotyping of the control embryos (Group B).

\begin{tabular}{|c|c|c|c|c|c|c|c|c|}
\hline \multirow[b]{3}{*}{ Exp } & \multicolumn{4}{|c|}{ Blastocysts } & \multicolumn{4}{|c|}{ Compact morulas } \\
\hline & \multicolumn{4}{|c|}{ typed } & \multicolumn{4}{|c|}{ typed } \\
\hline & no embryos & male & female & not typed & no embryos & male & female & not typed \\
\hline 1 & 3 & 0 & 2 & 1 & 0 & 0 & 0 & 0 \\
\hline 2 & 5 & 3 & 0 & 2 & 5 & 0 & 0 & 3 \\
\hline 3 & 13 & 1 & 3 & 9 & 7 & 1 & 3 & 3 \\
\hline 4 & 15 & 4 & 4 & 9 & 4 & 0 & 1 & 3 \\
\hline 5 & 4 & 2 & 0 & 2 & 0 & 0 & 0 & 0 \\
\hline Total & 40 & 8 & 9 & 23 & 14 & 1 & 4 & 9 \\
\hline
\end{tabular}


Table 3. Total number of embryos which could be karyotyped in the $\mathrm{H}-\mathrm{Y}$ antibody (A) and the control group (B).

\begin{tabular}{lccccccc}
\hline & & \multicolumn{6}{c}{ No embryos } \\
\cline { 3 - 8 } Group & no embryos & not typed & typed & male & female & $\%$ typed & sex ratio \% \\
\hline A & 72 & 36 & 36 & 21 & 15 & 50 & 58 \\
B & 54 & 32 & 22 & 9 & 13 & 41 & 41 \\
\hline Total & 126 & 68 & 58 & 30 & 28 & 45 & 52 \\
\hline
\end{tabular}

square $=16.364, \mathrm{p}=0.000, \mathrm{DF}=1)$. In the control group (B), 8 males and 9 females versus 1 male and 4 females were found in the blastocyst and compact morula groups, respectively. This difference was not statistically different (chi square $=1.170, \mathrm{p}=$ $0.279, \mathrm{DF}=1)$.

Only $40-50 \%$ of the embryos could be karyotyped. The proportion of males for the total group of embryos was $52 \%$ with $58 \%$ in group A and $41 \%$ in group B embryos. This difference was not significant (chi square $=1.660, \mathrm{p}=0.198, \mathrm{DF}=1$ ).

The limiting factors for proper karyotyping were lack of metaphases $(17 \%)$, poor preparation (25\%) and gross chromosomal abnormality (12\%); the latter was found among embryos of quality $\mathrm{c}(\mathrm{n}=24,3$ haploids, 1 triploid, 2 tetraploids and 2 polyploids).

Embryos which could not be karyotyped were omitted from the statistics, since their developmental stages were distributed not significantly different from that of the typed embryos. (A embryos: chi square $=1.399, \mathrm{p}$ $=0.237$; $\mathrm{B}$ embryos: chi square $=0.198, \mathrm{p}=$ 0.657).

The number of experimental (A) and control (B) embryos that could be karyotyped did not differ significantly from each other either (chi square $=1.619, \mathrm{p}=0.203, \mathrm{DF}=$ 1).
In addition to these 5 experiments a 6 th experiment was performed, where $6 \mathrm{H}-\mathrm{Y}$ antibody treated embryos of excellent quality from one donor were transferred to 6 recipients. The embryos were flushed non-surgically. After $13 \mathrm{~h}$ in culture 2 groups could be distinguished: $3 \mathrm{BL}$ and $3 \mathrm{CM}$. After wash in $\mathrm{H}-\mathrm{Y}$ antibody free medium, they were transferred separately to 6 recipients.

The outcome of the 6 th experiment was not conclusive. Three cows did not become pregnant, 2 had prolonged cycles (day 29 and day 50) and one gave birth to a male calf, resulting from a compact morula.

\section{Discussion}

The method described in this paper was based on culture in $\mathrm{H}-\mathrm{Y}$ antibody containing medium followed by karyotyping of whole embryos. The purpose was to test if our H-Y antibody could discriminate between male and female embryos. The results presented demonstrate that early embryonic development and thus the sex of bovine embryos was influenced by the antibody. These observations are in accordance with findings by other groups (King 1984, Hare et al. 1976, Picard et al. 1984, Rall \& Leibo 1987, Singh \& Hare 1980, WinterbergerTorres \& Popescu 1980).

In our 6th experiment the pregnancy rate was lower than expected, since only $1 \mathrm{em}$ - 
bryo of 6 resulted in offspring. It is very likely that prolonged cell culture contributed to this decrease in embryo viability, as described by Renard et al. (1980a, b).

In agreement with Utsumi $(1983,1984)$ we emphasize that this method requires embryos at the compact morula stage. In our initial experiments we cultured mouse embryos from the 4-8 cell stages in H-Y antibody with no effect on their development until they reached the compact morula stage. Then their development deviated, and it was possible to find a blastocyst versus a compact morula group. Later stages i.e., blastocysts were equally unaffected by the H-Y antibody treatment.

By means of immunofluorescence H-Y antigen has been detected on mouse embryos from the 8-cell stages, but not on the 4-cell stages. It is easily detected on 8-cell mouse embryos and on morulas, but is more difficult to detect on blastocysts (Wachtel 1984, Anderson 1987).

White et al. (1987) were able to demonstrate fluorescence on the inner cell mass, but not on trophectoderm cells from bovine expanded blastocysts, proposing that this distribution of $\mathrm{H}-\mathrm{Y}$ antigen could be protecting the implanting embryo from rejection by the maternal organism.

H-2 antigens, which are major histocompatibility antigens in the mouse (MHC), are expressed on mouse embryos. Goldbard et al. (1985) showed by means of monoclonal anti-H-2-antibody that all stages from unfertilized eggs to blastocysts synthesize $\mathrm{H}-2$ antigens, but it becomes increasingly difficult to demonstrate on blastocysts, and it is generally believed that the antibody is unable to penetrate to the blastocele, so only H-2 antigens on the outside of the blastocysts are detected.
The H-Y antigen system, although not a MHC could act in the same way and this would explain its inability to control blastocyst development. It is unclear though why the development of male embryos is retarded in $\mathrm{H}-\mathrm{Y}$ antibody containing medium, but a possible explanation could be capping and internalization of the $\mathrm{H}-\mathrm{Y}$ antigen/H-Y antibody complex on the male embryos, an energy requiring reaction, which might delay development.

Another explanation could be that H-Y antigen could act as a male growth regulator as stated by Mittwoch (1977), and that H-Y antibody could inhibit this regulation.

The most commonly used sexing method, based on $\mathrm{H}-\mathrm{Y}$ antibodies is the indirect immunofluorescent method, where the male embryos after a brief incubation $(30 \mathrm{~min})$ in $\mathrm{H}-\mathrm{Y}$ antibody are labelled with FITC-labelled-goat-anti-mouse-immunoglobulin. This method is fast but requires an inverted fluorescence microscope. The sorting and evaluation of embryos is highly subjective and a considerable experience is needed in order to avoid false positive reactions. Embryo viability has by some groups been reported unaffected, while others find it decreased (White et al. 1985, 1987, Anderson 1987).

The major advantages of the Utsumi method i.e. the method described in this study are independence of elaborate equipment and applicability on porcine embryos (Avery 1987). Due to the high number of sperm in the zona of fertilized porcine embryos, the fluorescence method is not feasible, but requires removal of the zona before FITClabelling. The disadvantages of the Utsumi method are relatively long incubation periods, having negative effect on embryo viability, and suitable embryo stages strictly limited to compact morulas. 


\section{Conclusion}

The H-Y antibody used in these experiments seems to be able to distinguish between male and female bovine embryos with the same accuracy as described by other authors.

The use of $\mathrm{H}-\mathrm{Y}$ antibodies is only one of the possible methods available for preimplantatory sexing, but none of the methods are at the moment suitable "in the field". At present we are investigating alternative methods, especially the possible correlation between early embryonic development and sex.

\section{Acknowledgements}

The authors are grateful to Ms. I. Heinze for valuable technical assistance and to Ms. P. Hoffmann for typing the manuscript. This project was funded by The Danish Agricultural and Veterinary Research Council.

\section{References}

Anderson $G B$. Identification of embryonic sex by detection of $\mathrm{H}-\mathrm{Y}$ antigen. Theriogenology 1987, 27, 81-97.

Avery $B$ : Embryo sexing. In proceedings of symposium: "Application of egg- and embryotechnologies to domestic anımals" (Ed. T. Greve), Copenhagen 1987, p. 21-23.

Avery $B$, Schmidt $M$, Greve $T$. Sex determination of bovine embryos based on embryonic cleavage rates. Acta vet. scand. 1989, 30, 147-153.

Bennet $D$, Boyse $E A$ Sex ratio in progeny of mice inseminated with sperm treated with $\mathrm{H}-\mathrm{Y}$ antiserum. Nature 1973, 246, 308-309.

Bradley MP, Heslop BF. An improved urease Elisa protocol for the screening of monoclonal H-Y antibodies. Proc. Univ. Otago med. School 1984, 62, 14-15.

Brunner M, Moreira-Filho CA, Wachtel $G$, Wachtel $S$ : On the secretion og $\mathrm{H}-\mathrm{Y}$ antigen. Cell 1984, 37, 615-619.

Dooher GB, Bennett $D \cdot$ A simple technique for preparing easy to read, permanent cytotoxicity tests on mouse spermatozoa. Transplantation 1977, 23, 381-383.
Elchwald EJ, Silmser CR Untitled publication. Transplantation Bulletin 1955, 2, 148-149.

Epstein CJ, Smith S, Travis B: Expression of $\mathrm{H}-\mathrm{Y}$ antigen on preımplantation mouse embryos. Tissue Antigens 1980, 15, 63-68.

Gefter $M L$, Margulles $D H$, Sharff $M D \cdot$ A simple method for polyethylene glycol promoted hybridization of mouse myeloma cells. Somatic cell genetics 1977, 3, 231-236.

Goding $J W$. Antibody production by hybridomas. J. immunol. meth. 1980, 39, 286-308.

Goldbard SB, Gollnick SO, Warner CM. SyntheS1s of $\mathrm{H}-2$ antigens by preimplantation mouse embryos. Biol. Reprod. 1985, 33, 30-36.

Goldberg EH, Boyse EA, Bennett D, Scheld M, Carswell EA. Serological demonstration of $\mathrm{H}-\mathrm{Y}$ (male) antigen on mouse sperm. Nature 1971, 232, 478-480.

Hare WCD, Mitchell D, Betteridge KJ, Eaglesome $M D$, Randall $G C B$ : Sexing two week old bovine embryos by chromosomal analysis prior to surgical transfer: Preliminary methods and results. Theriogenology 1976, 5, 243-253.

Hoppe PC, Koo GC . Reacting mouse sperm with monoclonal $\mathrm{H}-\mathrm{Y}$ antibodies does not influence sex ratio of eggs fertilized in vitro. J. Reprod. Immunol. 1984, 6, 1-9.

Kenneth RH, McKearn TJ Monoclonal antibodies. Hybridomas: A new dimension in biological analyses. Plenum press, N.Y. and London 1980.

King WA Sexing embryos by cytological methods. Theriogenology 1984, 21, 7-17.

King WA, Linares T, Gustavsson I, Bane A A method for preparation of chromosomes from bovine zygotes and blastocysts. Vet. Sci. Commun. 1979, 3, 51-56.

King WA, Guay P, Picard L: A cytogenetical study of 7-day old bovine embryos of poor morphological quality. Genome 1987, 29, 160 -164 .

Koo GC, Stackpole CW, Boyse EA, Hammerling $U$, Lardis MP. Topographical location of $\mathrm{H}-\mathrm{Y}$ antigen on mouse spermatozoa by immunoelectron microscopy. Proc. Nat. Acad. Sci. (USA) 1973, 70, 1502-1505.

Krco CJ, Goldberg EH' Detection of H-Y (male) antigen on 8-cell mouse embryos. Science 1976, 193, 1134-1135. 
Krupen-Brown K, Wachtel SS. Cytotoxic and agglutinating $\mathrm{H}-\mathrm{Y}$ antibodies in multiparous female mice. Transplantation 1979, 27, 6, 404-409.

Köhler $G$, Milstein $C$ Continous cultures of fused cells secreting antibody of predefined specificity. Nature 1975, 256, 495-497.

Lindner $G$, Wright Jr. $R W$ Bovine embryo morphology and evaluation. Theriogenology 1983, 20, 4, 407-416.

Meck JM, Goldberg EH' Serological detection of $\mathrm{H}-\mathrm{Y}$ antigen in humans with a cellular-radioimmunobinding assay and monoclonal antibody. J. Immunol. Meth. 1984, 73, 293-299.

Melvold RW, Kohn HL, Yerganian G, Fawcett $D W$ Evidence suggesting the existence of two $\mathrm{H}-\mathrm{Y}$ antigens in the mouse. Immunogenetics 1977, 5, 33-41.

Mittwoch $U: \mathrm{H}-\mathrm{Y}$ antigen and the growth of the dominant gonad. J. Med. Genet. 1977, 14, 335 -338 .

Nagamıne C, Reıdy J, Koo GC. A radiobinding assay for human $\mathrm{H}-\mathrm{Y}$ antigen using monoclonal antibodies. Transplantation 1984, 37, 13-17.

Nakamura D, Wachtel SS, Kallman K: H-Y antigen and the evolution of heterogamety. J. Hered. 1984, 75, 353-358.

Picard L, King WA, Betteridge KJ. Cytological studies of bovine half-embryos. Theriogenology 1984, 21 (abstr)

Pledrahita JA, Anderson GB: Investigation of sperm cytotoxicity as an indicator of ability of antisera to detect malespecific antigen on preimplantation mouse embryos. J. Reprod. Fertil. 1985, 74, 637-644.

Rall WF, Leibo SP. Production of sexed bovine pregnancies by cytogenetic analysis of cultured demi-embryos. Theriogenology 1987, 27, 269 (abstr.).

Renard J-P, Heyman Y, Ozll J-P: Importance of gestation losses after non-surgical transfer of cultured and non-cultured bovine blastocysts. Theriogenology 1980a, 13, 109.

Renard J-P, Heyman Y, Ozil J-P. Importance of gestation losses after non-surgical transfer of cultured and non-cultured bovine blastocysts. Vet. Rec. 1980b, 197, 152-153.
Shelton JA, Goldberg EH. Male restricted expression of $\mathrm{H}-\mathrm{Y}$ antigen on preimplantation mouse embryos. Transplantation 1984, 37, 7-9.

Stlvers WK, Wachtel SS $\mathrm{H}-\mathrm{Y}$ antigen: Behaviour and function. - Science 1977, 195, 956960.

Singh EL, Hare WCD: The feasibility of sexing bovine morula stage embryos prior to embryo transfer. Theriogenology 1980, 14, 421-427.

Utsumı K, Satoh E, Yuhara $M \cdot$ Sexing of mammalian embryos exposed to $\mathrm{H}-\mathrm{Y}$ antisera. Proc. 2nd Int. Cong. Reprod. Immun. Kyoto, Japan. J. Reprod. Immunol. Suppl. 1983, p. 59.

Utsumı $K$, Satoh E, Yuhara $M$ - Sexing of goat and cow embryos by rat $\mathrm{H}-\mathrm{Y}$ antibody. Proc. 10th Int. Congr. Anim. Reprod. and AI. University of Illinois, Urbana, II 1984, p. 234.

Wachtel SS, Koo GC, Zuckerman EE, Hammerling $U$, Scheid MP, Boyse EA. Serological crossreactivity between H-Y (male) antigens of mouse and man. Proc. Nat. Acad. Sci. (USA) 1974, 71, 1215-1218.

Wachtel SS, Koo GC, Boyse EA: Evolutionary conservation of $\mathrm{H}-\mathrm{Y}$ (male) antigen. Nature 1975, 254, 270-272

Wachtel SS $\cdot \mathrm{H}-\mathrm{Y}$ antigen and the biology of sex determination. Bruce and Stratton, New York 1983.

Wachtel SS: H-Y antigen in the study of sex determination and control of sex ratio. Theriogenology 1984, 21, 18-28.

Wachtel GM, Wachtel SS, Nakamura D, Moreira-Filho CA, Brunner $M$, Koo GC. $\mathrm{H}-\mathrm{Y}$ antibodies recognize the $\mathrm{H}-\mathrm{Y}$ transplantation antigen. Transplantation 1984, 37, 8-13.

White KL, Lindner GM, Anderson GB, BonDu rant $R H$ Survival after transfer of "sexed" mouse embryos exposed to H-Y antisera. Thenogenology 1982, 18, 655-662.

White KL, Lindner GM, BonDurant RH: Cytolytic and fluorescent detection of $\mathrm{H}-\mathrm{Y}$ antigen on preimplantation mouse embryos. Theriogenology 1983, 19, 701-705.

White KL, Bradbury MW, Anderson GB, BonDurant $R H^{\cdot}$. Immunofluorescent detection of a male-specific factor on preimplantation bovine embryos. Theriogenology 1984, 21, 275. 
White KL, Anderson GB, BonDurant RH, Donahue $S E$, Pashen $R L \cdot$ Viability of bisected bovine embryos after detection of $\mathrm{H}-\mathrm{Y}$ antigen. Theriogenology 1987, 27, 1, 293.

White KL, Anderson GB, Berger PJ, BonDurant $R H$, Pashen $R L$ : Expression of a male-specific factor (H-Y antigen) on preimplantation porcine embryos. J. An. Sci. Vet. Suppl. Proc. Ann. Mtg. Am. Soc, Sci., University of Georgia, Athens GA 1985 (abstr.).

White KL, Anderson GB, BonDurant RH' Expression of a malespecific factor on various stages of preimplantation bovine embryos. Biology of reproduction 1987, 37, 873-897.

Wintenberger-Torres S, Popescu PC: Transfer of cow blastocysts after sexing. Theriogenology 1980, 14, 309-318.

Yelton DE, Diamond BA, Kwan S-P, Sharff MD. Fusion of mouse myeloma and spleen cells. Curr. Top. Microbiol. Immunolog. 1978, 81, 1-7.

Zaborskı P: Detection of $\mathrm{H}-\mathrm{Y}$ antigen on mouse sperm by the use of Staphylococcus aureus. Transplantation 1979, 27, 348-350.

\section{Sammendrag}

Konsbestemmelse af bovine embryoner ved hjolp af $\mathrm{H}-\mathrm{Y}$ antistoffer

Seks dage gamle embryoner $(n=126)$ blev opsamlet fra 8 superovulerede køer eller kvier, enten ved ikke-kirurgisk skylning eller ved skylning efter slagtning. Embryonerne, som var på morulastadiet, blev delt $i$ en forsøgsgruppe $(n=72)$ og en kontrolgruppe $(\mathrm{n}=54)$, som var sammenlignelige med hensyn til kvalitet og udviklingsstadier, bedømt ved morfologiske kriterier.

Embryonerne blev enten dyrket i Hams F-10 medium eller i Dulbeccos PBS tilsat $10 \%$ føtalt kalveserum (FCS), ved $38^{\circ} \mathrm{C}$ i $5 \% \mathrm{CO}_{2} / 95 \%$ atmosfærisk luft og $100 \%$ fugtighed. Forsøgsgruppens embryoner blev dyrket $i$ et af de ovennæunte medier fortyndet 1:1 med supernatant fra det monoklonale $\mathrm{H}-\mathrm{Y}$ antistof. Efter dyrkning i ca. 10 timer havde $54 \%$ (39) af embryonerne nået blastocyststadiet, mens $46 \%$ (33) forblev på morulastadiet. I kontrolgruppen sås $74 \%$ (40) blastocyster og $26 \%$ (14) morulae.

Karyotypning med kønsbestemmelse kunne udføres for 36 af de $\mathrm{H}-\mathrm{Y}$ antistof behandlede embryoner $(50 \%)$. I blastocystgruppen fandtes 7 hanner og 15 hunner, og i morula gruppen var der 14 hanner og 0 hunner. Kønsforskellen mellem de to grupper var statistisk signifikant. I kontrolgruppen kunne 22 embryoner karyotypes (41\%) med 8 hanner og 9 hunner $i$ blastocystgruppen og 1 han og 4 hunner i morulagruppen. Disse fordelinger afveg ikke fra den forventede 1:1 fordeling.

Begrænsende for korrekt karyotypning var manglende og/eller inkomplette metafaser eller præparater hvor detaljer ikke kunne skelnes.

Det konkluderes, at $\mathrm{H}-\mathrm{Y}$ antistoffet kan udøve en effekt på kønsfordelingen, når det anvendes på morulastadier, ved at hæmme hanembryonernes udviklıng reversibelt, så de forbliver på morulastadiet, mens hunembryonerne ikke påvirkes, men udvikles videre til blastocyststadiet.

(Recelved January 1, 1988, accepted August 11, 1988)

Reprints may be requested from: B. Avery, Department of Reproduction, Royal Veterinary and Agricultural University, Bülowsvej 13, DK-1870 Frederiksberg C, Denmark. 